
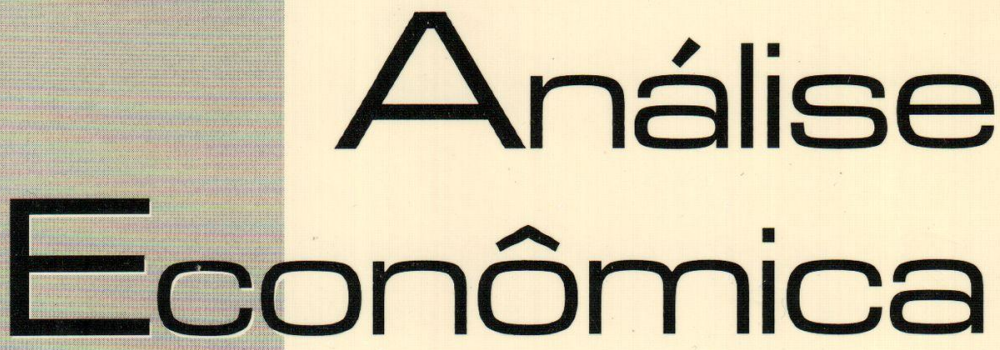

FATOS ESTHLIZADOS E CORRELAÇÁ O NO SETOR BANCÁRIO BRASILEIRO

IGOR AlexandRe C. DE MORAES

Política Monetária, Expectativas e Derivativos: uma ANALISE DO BRASIL PERIODO 1995-98

ROGERIO SOBREIRA

O FEDERAL RESERVE EM DOIS MOMENTOS DISTINTOS: ATUAÇÃO NA GRANDE DEPRESSÃO E NO FINAL DOS ANOS 1990

ROBSON RODRIGUES PEREIRA

BASHLÉIA 2 E ECONOMIAS EMERGENTES: UMA ABORDAGEM MÉDIA-VARIÁNCIA

otaViano Canuto e ANTÓ Nio josé MEIRELLES

VULNERABILIDADES EXTERNAS E INTERNAS DAS ECONOMIAS EMERGENTES E PADRÁ O DE CONTÁ GIO. A EXPERIÉnCIA DA DECADA DE 90

MiLTON PEREIRA OE ASSIS

ENDIVIDAMENTO PÚ BLICO E IMPACTO SOBRE FLUXOS DE CAPITAIS, RISCO-PAIS DIFERENCIAL DE JUROS NO BRASIL (1995-2002): MODELO VAR E TESTES DE CAUSALIDADE FLÁ VIO VILELA VIEIRA

METAS SOCIAIS DE PROCRAMAS DE MICROCRÉ DITO FINANCEIRAMENTE VIÁ VEIS

FERNANDO BATISTA PEREIRA E MARCO CROCCO

Estrutura Produtiva e Performance econó mica das ECONOMIAS ESTAdUAIS BRAsILIRAS NA DECADA DE NOVENTA ADELAR FOCHEZATTO

HISTORIA ECONO MICA Y TEORIA ECONO MICA: ENCUENTROS Y DESENCUENTROS

Gabriel PorciLe

EM BUSCA DA NOÇÃ O EVOLUCIONÁRIA (NEO-

SHUMPETERIANA) DO AUTO-INTERESSE DOS AGENTES: UMA CONTRIBUIÇAO A PARTIR DA LITERATURA SOBRE COOPERAÇÁO INTERFIRMAS

ROBSON ANTONIO GRASS

PRINCiPIOS E APULAÇó Es de REGRESSÁo Local ADALMIR MARQUETTI E LORI VIAL

globalizaçáo, Crescimento e pobreza, a Visäo do BANCO MUNDIAL SOBRE OS EFETTOS DA GLOBALIZAÇÁO NALI DE JESUS DE SOUZA

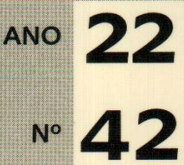




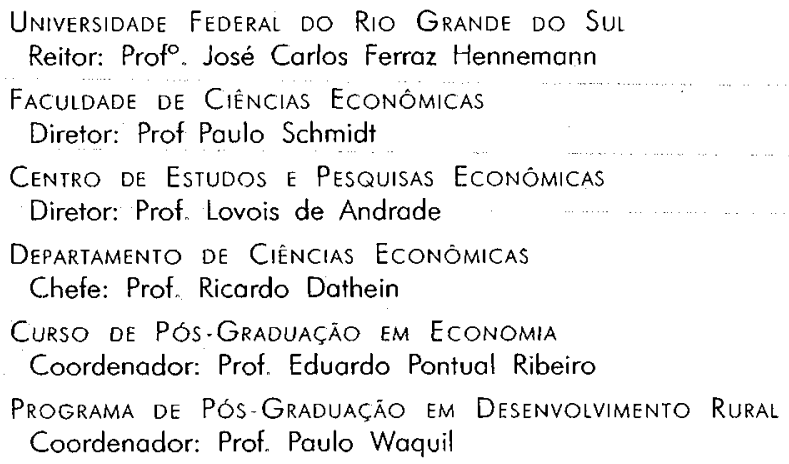

CONSELHO EDITORIAL:

André M. Cunha (UFRGS), Carlos G. A. Mieliz Netto (UFRGS), Carlos H. Hom (UFRGS), Eduardo $A_{n}$ Maldonado Filho (UFRGS), Eduardo P. Ribeiro (UFRGS), Eleutério F. S. Prado (USP), Eugênio Lagemann (UFRGS), Fernando Cardim de Carvalho (UFRJ), Fernando Ferrari Filho (UFRGS), Fernando de Holanda Barbosa (FGV/RJ), Flávio Vasconcellos Comim (UFRGS), Flávio A. Ziegelman (UFRGS), Gentil Corazza (UFRGS), Giácomo Balbinotto Netto (UFRGS), Gilberto de O. Kloeckner(UFRGS), Gustavo Franco (PUC/RJ), Hélio Henkin (UFRGS), Jairo L. Procianoy (UFRGS), Jan A. Kregel (UNCTAD), João Rogério Sanson (UFSC), Joaquim Pinto de Andrade (UnB), Jorge Paulo Araújo (UFRGS), José R. Iglesias (UFRGS), Júlio C. Oliveira (UFRGS), Luis P. Nogueról (UFGS), Luiz E. Faria (UFRGS), Marcelo S. Portugal (UFRGS), Maria Alice Lahorgue (UFRGS), Octávio A. C. Conceição (UFRGS), Orlando Martinelli (UFRGS), Paul Davidson (University of Tennessee), Paulo D. Waquil (UFRGS), Paulo Schmidt (UFRGS), Pedro C. D. Fonseca (UFRGS), Philip Arestis (University of Cambridge), Ricardo Dathein (UFRGS), Roberto C. de Moraes (UFRGS), Ronald Otto Hillbrecht (UFRGS), Sérgio M. M. Monteiro (UFRGS), Sabino da Silvo Porto Jr. (UFRGS), Stefano Florissi (UFRGS) e Werner Baer (University of Illinois at Urbana-Champaign).

COMISSÃO EDITORIAL:

Eduardo Augusto Maldonado Filho, Fernando Ferrari Filho, Gentil Corazza, Marcelo Savino Portugal, Paulo Dabdab Waquil e Roberto Camps Moraes.

EDITOR: Prof. Fernando Ferrari Filho

Egitor Adunto: Prof Gentil Corazza

Secretário: Paulo Roberto Eckent

REVISÁO DE TEXTOS: Vanete Ricacheski

Eottoraçáo Eletrónca: Nucleo de criação e editoraçáo Gráfica UFrgs: leonardo ponso Fundador: Prof. Antônio Carlos Santos Rosa

Os materiais publicados na revista Análise Econômica são da exclusiva responsabilidade dos autores. É permitida a reprodução total ou parcial dos trabalhos, desde que seja citada a fonte. Aceita-se permuta com revistas congêneres. Aceitam-se, também, livros para divulgação, elaboração de resenhas e recensōes Toda correspondência, material para publicação (vide normas na terceira capa), assinaturas e permutas devem ser dirigidos ao seguinte destinatário:

PROF. FERNANDO FERRAR! FILHO

Revista Análise Econômica - Av. João Pessoa, 52 CEP 90040-000 PORTO ALEGRE - RS, BRASIL Telefones: (051) 316-3513 - Fax: (051) 316-3990

Análise Econömíca E-mail: rae@ufrgs.br

Ano 22, $n^{\circ} 42$, morço, 2004 - Porto Alegre

Faculdade de Ciências Econômicas, UFRGS, 2004

Periodicidade semestral, março e setembro.

Tiragem: 500 exemplares

1. Teoria Econômica - Desenvolvimento Regional -

Economia Agrícola - Pesquisa Teórica e Aplicada.

Periódicos. 1. Brasil.

Faculdade de Ciências Econômicas,

Universidade Federal do Rio Grande do Sul. 


\title{
Metas sociais de programas de microcrédito financeiramente viáveis
}

\author{
Fernando Batista Pereira ${ }^{1}$ e ${\text { Marco } \text { Crocco }^{2}}^{2}$
}

Resumo: O texto avalia a proposta de programas de microcrédito de conciliar o atendimento da população de baixa de renda, a partir de uma estrutura financeira viável. Para tanto, o trabalho está dividido em três seções, além da introdução. A primeira segunda seção discute, no campo teórico, os limites da meta social de um programa que prioriza a viabilidade de sua carteira. A terceira seção expõe o caso do Banco Popular, através de uma análise sobre a natureza sócio-econômica do seu quadro de clientes. Na seção final, as conclusōes apontam que o objetivo de viabilidade da carteira tende a subordinar a proposta de atendimento às camadas de mais baixa renda.

Palavras-chave: microcrédito, programa financeiramente auto-sustentável, objetivo social.

Abstract: This piece aims analyzing the microcredit programme of the Banco Popular de Ipatinga (Minas Gerais - Brazil) focusing on the possibility of the program to supply credit service to the low-income population together with a sustainable financial structure. The article is divided in three parts, besides an introduction. The first one discusses, on the theoretical grounds, the possibility of a microcredit programme to conciliate its financial feasibility together with its social targets. The second part analyses the social and economic features of Banco Popular's customers. Finally, on the conclusion, the authors argued that the objective of financial feasibility tends to constrain and subordinate the social objective of the programme.

Keywords: microcredit, sustainable financial structure, social targets.

Jell Classification:G2, O17e R51.

\section{Introdução}

O microcrédito, em geral, é definido como a concessão de crédito produtivo para microempresários de baixa renda. $\mathrm{O}$ objetivo está em atender a essa parcela da população, que nāo dispõe de patrimônio suficiente para assegurar uma operação de empréstimo, estando, portanto, excluída do acesso (ou cujo acesso

1 Mestre em Economia, Cedeplar - UFMG, 2004. e-mail: batista@cedeplar.ufmg.br

${ }^{2}$ Ph.D. em Economia, University of London, 1999. Professor Adjunto do Departamento de Ciências Econômicas da UFMG. e-mail: crocco@cedeplar.ufmg.br 
não se dá em condições satisfatórias) aos serviços oferecidos pelas instituições que compõem o Sistema Financeiro Nacional (SFN). Para atender a esse objetivo, os programas de microcrédito procuram operar com metodologias próprias, baseadas em laços de relacionamento entre os participantes, de maneira a romper com o ciclo de escassez de garantias reais, em um movimento oposto ao do SFN. Além disto, a maioria dos programas (no país e no exterior) partem do princípio de que suas respectivas estruturas financeiras devem ser auto-sustentáveis.

Esse texto propõe avaliar os impactos desse projeto de viabilidade financeira sobre as metas sociais de um programa de microcrédito. Para isso, o texto está dividido em três seções, além desta introdução. A segunda seção aborda duas questões teóricas: de início, há uma exposição da metodologia de funcionamento do microcrédito; em seguida, há uma discussão sobre o que deve ser tratado como meta social de uma iniciativa de microcrédito que esteja amparada pelos moldes de sustentabilidade financeira.

A terceira seção trata do caso do Banco Popular de IpatingaMG, ONG relativamente bem-sucedida, que prioriza a viabilidade de sua carteira. Essa seção apresenta a linha de operação seguida pela instituição, assim como os resultados de uma pesquisa de campo, realizada sobre seu quadro de clientes. A motivação é avaliarmos dois aspectos: primeiramente, averiguar qual é seu campo de atuação, ou seja, a natureza de seus clientes efetivos. Em seguida, tratar a relevância dos serviços oferecidos. Para isso, utilizamos métodos de estatística descritiva, além de uma análise de componentes principais.

$\mathrm{Na}$ terceira seção, retornamos à discussão inicial, sobre o perfil da meta social de uma iniciativa de microcrédito financeiramente viável, para expormos as conclusões principais, que foram tiradas do estudo de caso.

\section{Microcrédito e o sistema financeiro nacional}

É fato estilizado que o conjunto de microempresários (ou de forma mais generalizada, a população de baixa renda), apesar da sua extensão, não representa um mercado atraente para as instituições do Sistema Financeiro Nacional. Três fatores, característicos deste tipo de cliente, explicariam este fato: a vulnerabilidade econô- 
mica do prestatário potencial, combinada com um colateral de porte insuficiente, em operações de baixo valor unitário.

Os dois primeiros elementos seriam os determinantes de um maior grau de risco operacional. Isso ocorre devido à própria natureza de uma microempresa, caracterizada por uma fragilidade técnica e financeira (baixa produtividade e pequeno poder de mercado), o que resulta em uma taxa de mortalidade - e conseqüente risco de default - expressiva. Esse risco de perda de capital do credor, por sua vez, não é devidamente protegido, por se tratar de um público com insuficiente oferta de garantias reais (riqueza patrimonial e renda não comprovada por documentos formais) que poderiam ser utilizadas como contraprestação em uma situação adversa. Finalmente, o baixo valor relativo dos serviços financeiros requeridos pelo microempresário não proporciona uma margem de rentabilidade atraente às entidades provedoras de crédito formal. Isso porque a metodologia de funcionamento desse sistema, ao amparar-se em um amplo aparelho burocrático, tendo em vista minimizar o risco e as perdas provenientes do não pagamento dos termos contratuais, representa um elevado custo operacional (PARENTE, 2003, p. 34-35).

Esse é um tema bastante presente na literatura econômica, que procura encontrar os motivos para essa "imperfeição" do mercado de crédito. $\mathrm{O}$ argumento defendido por autores de diferentes linhas de pensamento teórico (STIGLITZ e WEISS, 1981; DYMSKI, 1993; 1996, p. 1236; CANUTO, 2002, p. 132-133) para explicar o racionamento da oferta de crédito formal fixa-se sobre a existência de informação assimétrica. Assim, os participantes deste mercado não compartilham do mesmo grau de informação (e conseqüentemente do mesmo grau de confiança) sobre a possibilidade de sucesso do negócio e a capacidade de pagamento do potencial prestatário, inviabilizando a realização de estimativas convergentes sobre o risco da operação. Adiciona se a isto o elevado custo de transação para a obtenção das informações ausentes, especialmente dentro da estrutura de funcionamento praticada pelas entidades do Sistema Financeiro Nacional. O resultado é que o elevado custo de transação, confrontado com operaçōes de baixo valor financeiro presentes neste tipo de mercado, acaba por se refletir em significativo custo unitário. Dentro dessa estrutura, a rentabilidade da operação fica comprometida e sua realização passa a sustentar.se pela cobrança de alto preço (juros) para o serviço. 
São estes elevados custos de transações (o custo para o emprestador, em sua busca por informações que facilitem o estabelecimento contratual e o monitoramento da operação com baixo risco de default, e o custo para o tomador do empréstimo, definido pelo tempo e dinheiro associado ao atendimento das regras contratuais preestabelecidas), que, segundo alguns autores (BHATT e TANG, 1998, 1999; D'EXELLE, BASTIAENSEN e ALEMÁN, 2002), justificaria e estimularia a criação de organizações de microcrédito. Ou seja, como o custo de transação varia diretamente com o grau de formalidade contratual incorrido em uma operação de fornecimento de crédito, tais organizações deveriam possuir formas de funcionamento que reduzissem o grau de formalidade dessas operaçōes facilitando a concessão do crédito.

De modo geral, para que isto ocorra, as instituições de microcrédito desenvolveram formas de funcionamento específicas, capazes de estabelecer laços de confiança entre os atores participantes (credor e tomador), rompendo com o ciclo de falta de informação e o conseqüente alto risco operacional representado pelo potencial prestatário.

Um elemento presente em quase todas as organizações é o crédito assistido, expresso pela figura do agente de crédito. A proposta é que este funcionário atue como o elo de ligação e diálogo dentre os participantes da operação, sendo responsável por um trabalho de acompanhamento e monitoramento junto ao conjunto de tomadores de crédito. Através dessa maior proximidade, seria possível construir uma estrutura de relacionamento e confiança que atuasse como um substituto para a escassa garantia real disponível, conseqüentemente reduzindo o risco da operação, além de garantir uma maior agilidade e fluidez para a operação. (IBAM, 2001, p.119-120; SCHREINER, 2001, p. 4-7; BARONE et al., 2002 p. 31-32).

Segundo Bhatt e Tang (1998), as instituições de microcrédito devem seguir exatamente o mesmo caminho desenvolvido pelos setores ditos "informais" (crédito pessoal e até agiotagem), se quiserem se amparar em uma estrutura financeira auto-sustentável. De acordo com a linha de interpretação dos autores, os custos de transação são determinados pelas especificidades e arranjos organizacionais do contexto social no qual estão inseridos os potenciais tomadores de crédito. Desta forma, a saída estaria na inserção das instituições de microcrédito nesse ambiente, de modo que o 
aproveitamento deste "capital social" possibilitaria a eliminação de uma série de custos de transação, sem que isso pudesse comprometer uma elevada taxa de adimplência. $O$ argumento é que o maior conhecimento e o bom relacionamento existente entre as pessoas eliminariam custos de montagem de regras e contratos, reduzindo as despesas de monitoramento junto aos tomadores.

Daí a importância de se operar em conjunto com associações de moradores, sindicatos e grupos de microempresários, ou entidades filantrópicas, como organizações não-governamentais, igrejas ou mesmo políticas públicas que estejam presentes no desenvolvimento da vida de uma comunidade. Isso porque, mesmo que essas entidades e organizações não assumam uma postura ativa dentro da operação de crédito (isto é, sob a forma de avalista do empréstimo), exercem um papel fundamental para construção do capital social estabelecido dentre os membros de uma comunidade. Esse se constitui no ambiente ideal para a participação de um programa de microcrédito. ${ }^{3}$

Um outro mecanismo amplamente citado na literatura nacio. nal e internacional (como, por exemplo, BARONE et al., op. cit. p. 30-31, WRIGHT, 2000, p. 130-134) visando reduzir os custos de transações envolvidos em operações de crédito seria a formação de grupo de aval solidário ou coletivo. Em linhas gerais, o funcionamento desse mecanismo se caracteriza pela formação de um grupo de clientes que assumam, junto à instituição provedora de crédito, o compromisso de cumprimento e monitoramento das obrigações contratuais de todo o conjunto. O resultado é o rebaixamento dos custos administrativos e operacionais, de natureza financeira e também os chamados custos intangíveis. Vejamos o porquê.

Em primeiro lugar, o fato de as pessoas do grupo se responsabilizarem pelo cumprimento das operações do coletivo reduz os custos de monitoramento da operação (o custo deixa de ser individual e passa a abarcar todo o grupo). Adicionalmente, a posição do grupo, ao reunir uma riqueza patrimonial e assumir a condição de um avalista, acaba por reduzir não só o risco, mas também a

${ }^{3}$ A proposta apresentada por Toscano (2002, p. 4-10) caminha no sentido de construir mecanismos de integração econômica dentro dessa estrutura de relacionamento e vida comunitária (capital social). O objetivo seria fomentar - via cooperativas de produção e consumo, feiras populares ou iniciativas análogas - a formação de cadeias produtivas locais, incorporando o público-alvo de microempreendedores e fortalecendo assim o desenvolvimento econômico de todo o conjunto. 
perda de capital associada ao estado de default (muito embora é dificil prever que esse patrimônio tenha algum valor comercial).

Igual importância caberia aos elementos intangiveis, com a construção de um ambiente de confiança e relacionamento, no qual os indivíduos teriam identidade pessoal. Nesse sentido, Bhatt e Tang (1998) colocam que o grupo de aval solidário é um método eficiente para contenção dos custos de transação, uma vez que estes são incorporados ou internalizados na própria estrutura de ordem social vigente no grupo. O resultado é que a agência de microcrédito se colocaria numa posição vantajosa - análoga à dos credores do tipo pessoal ou informal - podendo se aproveitar do baixo custo de informação por cliente e conseqüente baixa taxa de risco.

Bhatt e Tang (1998) assinalam a importância de que a formação de grupos deve ser tratada como um processo de construção institucional, cujos arranjos possíveis irão depender do modo de organização e interação econômica, social e cultural existente entre as pessoas. Seguindo essa lógica, os autores desenvolveram uma classificação simples, mas ilustrativa, do grau de capital social constituído em um grupo de pessoas e os efeitos gerados sobre os custos de transação. Nesse sentido, tem-se no limite grupos coesos, caracterizados por normas sociais comuns, o que se reflete em um grau de confiança e responsabilidade mútua que dispensa a participação ativa da agência de microcrédito, representando um baixo custo de transação para ambas as partes. Nas palavras dos autores, os custos de transação seriam aqui "internalizados" dentro da própria estrutura de relacionamento pessoal (1998, p. 629-631).

Por outro lado, em determinados ambientes sociais, por uma série de motivos - fluxo de migração recente ou diferenças sócioculturais intrínsecas -, o processo de construção do capital social não atingiu resultados adequados (ou sequer teve início). Esse contexto imporia a necessidade de uma postura mais ativa por parte da instituição de microcrédito para desenvolvimento dessa estrutura pessoal, incorrendo em custos de transação mais elevados, tanto para o credor como também para o prestatário (que teria de realizar um esforço maior para lidar com os membros de seu grupo). O resultado deste processo, ainda em fase de construção, é que a instituição não teria como exigir a mesma contrapartida do conjunto de prestatários, ou seja, não apenas a etapa prévia, mas os períodos subseqüentes (durante e mesmo pós-operacional) exigiriam uma maior participação da instituição prestadora do microcrédito. 
Toda essa discussão dos métodos utilizados, visando a um maior acesso da população de baixa renda ao crédito, está inserida em uma outra discussão maior acerca do objetivo final dos programas de microcrédito: instrumento de combate à pobreza ou de fomento às iniciativas econômicas da parcela do público "financeiramente excluído". Dentro desse contexto, um grande debate tem girado em torno da necessidade ou não da sustentabilidade financeira dos programas de microcrédito. A questão central é em que medida esta necessidade se contrapõe, ou não, aos objetivos sociais do programa.

Esta questão está sendo colocada porque o microcrédito, nos moldes de independência financeira, chegou a ser entendido como uma ferramenta de redução ou mesmo eliminação da pobreza mundial (YARON, BENJAMIN e CHARITONE, 1998, p. 148; SCHREINER, 2001, p. 1; DALEY-HARRIS, 2002). No entanto, as evidências empíricas (HULME e MOSLEY, 1996; BHATT e TANG, 1998, p. 624; 1999, p. 4-5; MORDUCH, 2000) - particularmente no Brasil (BARONE et al., 2002, p. 41-43; NICHTER, GOLDMARK e FIORI, 2002, p. 43-44) - têm constatado um tímido poder de penetração da grande maioria das instituições, junto às camadas mais pobres da população. Diante disso, ainda é possível considerarmos o microcrédito, sob o perfil atual, como arma contra a pobreza?

Sob esse aspecto, tem-se verificado uma profunda divergência entre duas linhas de pensamento: os "institucionalistas" e o denominado grupo de promoção do "bem-estar social" (welfarists), segundo classificação sugerida por Woller, Dunford e Woodworth (1999). ${ }^{4}$ Em linhas gerais, os institucionalistas defendem a plena conciliação do objetivo social de combate à pobreza com o aparato institucional de independência financeira. Segundo essa corrente, predominante no debate internacional sobre a montagem da estrutura do sistema de microcrédito (GONZÁLES VEGA et al, 1996, p. 13-14; YARON, BENJAMIN e CHARITONE, 1998, p. 148-149), a auto-sustentabilidade financeira não deve ser tratada como um objetivo per se, mas simplesmente como a maneira mais eficiente de se atingir a meta social de combate à pobreza. Para isso, seus defensores se utilizam duas constatações: primeiramente, evidências empíricas historicamente datadas já teriam demonstrado a capacidade do

${ }^{4} \mathrm{O}$ debate foi exposto, utilizando outra nomenclatura para descrever os atores participantes, no trabalho de Schreiner (1999). 
microcrédito, através da estrutura de funcionamento descrita acima, em operar com o público desprovido de garantias reais. De modo similar, esse público já teria apresentado capacidade em lidar com regras e valores de mercado em suas práticas financeiras (cabe lembrar que os próprios institucionalistas desconsideram o poder do microcrédito em atuar sobre o público classificado como "miséria absoluta"). ${ }^{5}$ Diante disso, o argumento é que, através de ganhos de escala (possibilitados por iniciativas de porte significativo), o custo operacional unitário poderia ser reduzido, a ponto de proporcionar viabilidade financeira ao negócio, mesmo nas práticas de cobertura junto às parcelas mais pobres.

Esta conclusão é veementemente refutada por autores que podem ser classificados como welfarists (WOLLER, DUNFORD e WOODWORTH, 1999; MORDUCH, 2000; TOSCANO, 2001; WOLLER, 2002). O argumento comum - que nos parece ser mais plausível - não está na negação das duas afirmativas citadas acima, mas na maneira com que os resultados são interpretados. Assim, muito embora o método do crédito assistido deva ser considerado um mecanismo adequado para o tratamento do público desprovido das garantias reais, isso não significa que o método seja capaz de reduzir o risco operacional associado a qualquer eventualidade externa que atinja um dado cliente.

No nosso entendimento, o principal ponto de divergência entre as duas linhas é um suposto adicional, adotado pelos welfarists (reconhecido, porém pouco enfatizado pelos institucionalistas), ${ }^{6}$ segundo o qual a população de renda mais baixa é intrinsecamente mais vulnerável a um choque externo qualquer. A partir daí, a conclusão é que a população mais pobre representa um natural risco de default, com proporções tais que desestimulam a ação incisiva das iniciativas voltadas para a independência financeira sobre esse público.?

5 Ver detalhes nos trabalhos de Navajas et al. (1998) e Schreiner (1999, p. 22).

6 Ver Schreiner (op. cit., p. 23).

7 Singer (2002, p. 7-11) explica que as práticas de mercado proporcionam resultados economicamente eficientes. No entanto, seu funcionamento se dá através de competição entre os agentes, o que promove a formação de "vencedores" e também de "perdedores". Esse processo ocorre ainda de forma cumulativa (inclusive entre gerações), de modo a criar uma divisão entre incluídos e excluídos. Em um dado ciclo expansivo, o incremento do produto pode ser compartilhado; porém, em situações adversas, os "perdedores" sāo automaticamente expulsos do mercado. 
Como colocado acima, segundo o pensamento institucionalista, a meta de combate à pobreza deve constituir-se no objetivo principal de uma iniciativa de microcrédito financeiramente autônoma, bastando para isso alcançar ganhos de escala operacional. Diversos autores (NICHTER, GOLDMARK e FIORI, op. cit, PARENTE, 2003) têm usado tal argumento para explicar o fracasso das instituições microcreditícias brasileiras, em atingir tal objetivo so. cial. Amparados pelas experiências internacionais de maior sucesso, como o BancoSol na Bolívia e o Bank Rakyat na Indonésia, essa linha de pensamento (NAVAJAS et al., 1998; SCHREINER, 1999) procura mostrar como é possível conciliar a lucratividade de uma instituição microfinanceira com uma taxa de penetração nas camadas sociais mais baixas. Isso já teria sido demonstrado pelas experiências citadas acima que, mesmo sem apresentar um percentual relativo significativo, ${ }^{8}$ teriam atingido valores absolutos expressivos.

Mais uma vez, mesmo sem refutar os dados apresentados por essas experiências, os welfarists argumentam que a lógica causal de que "eficiência financeira" se reverteria em "eficiência no combate à pobreza" é falsa. Conforme ressaltado por Woller, Dunford e Woodworth (op. cit., p. 46-47), a idéia é que os objetivos sociais e financeiros não necessariamente estão em conflito. No entanto, tal conflito vai ser, em geral, inevitável, em algum ponto do tempo (por exemplo, em uma crise de conjuntura), momento no qual o objetivo social passa a estar subordinado à meta financeira. Em nossas palavras, os autores procuram enfatizar a presença do componente de vulnerabilidade econômica nesse público, de modo que, nos momentos "bons", os mais pobres "podem" se tornar clientes potenciais e efetivos de uma instituição que prioriza o lucro. A lógica, porém, se reverteria automaticamente, em caso de cenários ou conjunturas adversas, em elementos de grande presença na vida econômica da população mais pobre. ${ }^{9}$

${ }^{B}$ A explicação para essa baixa penetração relativa estaria exatamente no fato de conciliação de metas distintas, ou seja, o foco não está unicamente voltado para esse público (SCHREINER, 1999).

9 O caso citado por YUNUS (op, cit. p193-197) exemplifica a impossibilidade de conciliação permanente das metas financeiras e sociais. O autor coloca que Bangladesh é marcada por uma série de catástrofes naturais, que muitas vezes destroem toda a economia de uma regiâo onde se sustentam seus clientes. A posição do Grameen - que ainda não conseguiu total independência dos subsidios - nessas situações, assume o caráter "assistencialista" de revisão dos pagamentos em um prazo indefinido, além da liberação imediata de empréstimos de urgência. 
Na nossa concepção, esse parece ser o raciocínio-mais consistente. De qualquer forma, é importante ressaltar que esse debate não visa ao simples questionamento sobre aspectos puramente teóricos e acadêmicos da questão do microcrédito. Ao contrário, dentro do escopo deste trabalho, entendemos ser fundamental estabelecer quais são os seus limites e o que deve ser esperado de uma instituição que atue sob determinada lógica de funcionamento. Queremos dizer com isso que não estamos procurando (assim como os autores citados da linha welfarist) desconsiderar a relevância de uma iniciativa de microcrédito financeiramente viável (voltada ou não para o lucro), mas simplesmente qualificar, de maneira mais objetiva, a sua meta social, que seria, no nosso entendimento, o de prestar serviço de crédito a um conjunto de pessoas (microempresários potenciais ou efetivos) financeiramen. te excluídas do SFN.

\section{$3 O$ banco popular de lpatinga- $M G$}

O Banco Popular (BP) é uma Associação Comunitária sem fins lucrativos que foi criada em junho de 1998, através de uma iniciativa da Prefeitura Municipal de Ipatinga-MG. Seu objetivo principal está no provimento do serviço de crédito para pequenas e microempresas, a partir de uma estrutura financeira auto-sustentável. Nesse sentido, o BP tenta aliar o princípio do atendimento de um público "excluído" do mercado de crédito, sem, no entanto, depender da atuação do poder público. Isso pressupõe duas regras operacionais: i) a fixação da taxa de juros do crediário é feita de modo a assegurar a cobertura total dos custos; ii) a busca por altos índices de adimplência, que assegurem o retorno e a sobrevida do capital aplicado.

A Prefeitura de Ipatinga foi motivada por desenvolver de uma instituição de microcrédito independente, nos moldes do terceiro setor. Para tanto, coube à prefeitura reunir aporte de recursos iniciais que possibilitaram a formação de uma estrutura de funding (fundo de crédito),$^{10}$ assim como a própria constituição do quadro operacional (o grupo de funcionários era inicialmente da prefeitu-

$10 \mathrm{O}$ aporte de recursos cedidos pela Prefeitura para formação do funding tinha o valor nominal de $\mathrm{R} \$ 120 \mathrm{mil}$ em 1998 . 
ra) e material da Associação. Com a aprovação da Nova Lei do Terceiro Setor, ${ }^{11}$ o Banco Popular passou a constituir, no ano 2001, uma OSCIP, assumindo oficialmente a autonomia com relação ao poder público municipal.

Por se tratar de uma instituição não-financeira, o Banco Popular, na qualidade de OSCIP, está impedido de obter recursos na forma de captação de poupança externa. Assim, a saída tem sido a realização de termos de parceira, firmados com iniciativas públicas, bancos de desenvolvimento e demais ONGs.

É importante esclarecermos que a preferência pela sustentabilidade financeira do programa impõe certos limites ao campo de atuação do Banco Popular. Isso ficará mais evidente na seção seguinte, ao tratarmos das exigências pré-operacionais requeridas pelo Banco, no que tange à viabilidade econômica e também à capacidade de pagamento por parte de seus clientes. Mais do que isso, é possivel percebermos, conforme explicitado no seu próprio estatuto social, que a motivação principal do programa não está em atingir as camadas mais pobres da população, mas em oferecer crédito ao conjunto de unidades produtivas (viáveis) que não dispõem de acesso aos serviços do SFN.

Segundo o regulamento operacional, o BP define como público-alvo empreendimentos com quadro máximo de dez empregados permanentes e quando o ativo patrimonial ultrapassar o montante de $R \$ 50$ mil. Além de medidas de restrição à riqueza de seus participantes, há também claros limites inferiores, colocados pela Associação. Isso fica explícito, a partir de exigências de "nome limpo" do cliente ou do avalista (consulta ao SERASA/ $\mathrm{SPC}$ ). Outro aspecto é o tempo mínimo requerido de funcionamento da atividade (seis meses), para que disponha do valor teto do crediário. $^{12}$

Fundamentalmente, as operações de crédito são oferecidas individualmente por prestatário. Embora esteja previsto em seu estatuto social, o mecanismo de crédito de aval solidário, na forma de grupo ou de associação, tem sido uma estratégia pou-

\footnotetext{
${ }^{11}$ Trata-se da lei 9.790/99, que estabelece regras para controle da natureza institucional das entidades do terceiro setor de direito privado sem fins lucrativos, que atuam no denominado espaço público não-estatal. O objetivo é firmar o "Termo de Parceria", uma estrutura de relacionamento dessas entidades para com o aparelho estatal (FERRAREZI, 2001).

${ }^{12}$ Empreendimentos novos estão condicionados à faixa entre $\mathrm{R} \$ 300,00$ a $\mathrm{R} \$ 500,00(10 \%$ do valor geral).
} 
co utilizada. Em conseqüência disso, o BP continua a operar com a metodologia tradicional, amparada por garantias e colaterais reais. Ou seja, o prestatário potencial depende da reunião de um patrimônio (ou de um avalista) suficiente para assegurar a realização do crediário. ${ }^{13}$

O quadro de serviços de empréstimos oferecidos possui uma estrutura bastante padronizada. ${ }^{14}$ Além disso, se ampara em valores e prazos contratuais relativamente baixos, como forma de alcançar um elevado índice de adimplência. ${ }^{15} \mathrm{O}$ resultado é o que podemos ver a seguir:

1. Crédito de capital Fixo: juros de 3,6\% para um intervalo entre $\mathrm{R} \$ 500,00$ e $\mathrm{R} \$ 5$ mil. Prazo máximo de 12 meses;

2. Crédito de capital de Giro: juros de 3,6\% para um intervalo entre $\mathrm{R} \$ 300,00$ e $\mathrm{R} \$ 3$ mil. Prazo máximo de 12 meses;

3. Crédito Rotativo (Troca de Cheques): juros de 3,4\% para um intervalo entre $\mathrm{R} \$ 300,00$ e $\mathrm{R} \$ 3$ mil. Prazo máximo de 9 meses.

O serviço de crédito rotativo é a simples "troca de cheques", na qual o cliente pode adiantar receitas futuras que assumam a forma de cheque pré-datado. O provimento desse serviço atende bem aos requisitos de baixo custo operacional e baixo risco, uma vez que envolve valores reduzidos (o valor de cada cheque pode atingir $15 \%$ do valor contratual), de curto prazo (máximo de sessenta dias) e que estão distribuídos sobre uma ampla gama de pessoas (o nome do titular do cheque não pode se repetir durante a mesma rodada).

A série histórica da taxa de inadimplência da Associação desde o período inicial de funcionamento apresenta valores que

13 Apesar desta característica, o Banco Popular vem desenvolvendo um conjunto de parcerias, formais e informais, envolvendo associação de moradores de bairros, sindicatos de microempreendedores, ONGs ou mesmo igrejas. Nesse aspecto, a motivação é a formação de uma estrutura sócio-econômica capaz de fortalecer a relação do Banco para com a clientela, assim como dentre os próprios clientes. Destaca-se aqui parceria firmada com a ONG italiana AVSI (Associação de Voluntários para o Serviço Internacional) que realizou um trabalho comunitário em Ipatinga (Jardim Planalto), transferindo para o Banco Popular o serviço de administração da etapa de fornecimento de crédito para seu público. 14 Embora previsto no estatuto, a oferta de serviços não-financeiros não tem sido diretamente provida pela associação, mas sim através de parcerias. Nesse aspecto, tem-se realizado uma integração com instituições, como Sebrae, Secretaria do Estado e a própria prefeitura, para oferecimento de cursos e seminários.

$15 \mathrm{O}$ argumento é que contratos de prazos curtos e com baixos valores monetários estimulariam a fidelidade do prestatário, uma vez que só o bom cumprimento da contraprestação permite que as operações possam ser renovadas. 
flutuam em uma banda entre $1,5 \%$ e $3,0 \%$. De certa forma, trata-se de um intervalo razoável, atendendo ao princípio básico do programa. ${ }^{16}$

A carteira ativa da instituição, ao final de 2002 , era de $R \$$ 1.141.637,04, um montante relativamente baixo, se consideradas as estimativas sobre a parcela de "excluídos" do mercado financeiro nacional (SCHOENDERGER, 2001; BARONE et. al., 2002; BRUSKY e FORTUNA, 2002, entre outros). No entanto, trata-se de uma iniciativa recente, que conta com imposições legais expressivas, o que, de certa forma, justifica seu ritmo de expansão. ${ }^{17}$

\subsection{Resultados da pesquisa de campo}

O objetivo de nossa pesquisa de campo foi o de levantar traços característicos do público mais participativo no programa do BP. Diante disso, nossa amostra ficou delimitada ao universo de clientes que realizou, ao menos, três operações de crédito (capital fixo e capital de giro), como forma de assegurarmos um grau de experiência, assim como um tempo de operação mínimo.

A pesquisa de campo foi realizada ao final de 2002 e envolveu uma amostra aleatória, composta por cerca de $36 \%$ dessa população (resultou em um conjunto de 76 entrevistas), e que foi distribuída na mesma proporção do número de operações do universo original. ${ }^{18}$

Para darmos início, a tabela 1 apresenta a distribuição amostral, segundo o sexo dos entrevistados, para cada faixa de número de operações de crédito. Fica evidente a predominância do sexo feminino, superioridade que ocorre em todas as faixas de operações realizadas. ${ }^{19}$

${ }^{16}$ Convém dizermos que o método de cálculo toma como referência o total das parcelas em atraso e não todo o restante do capital das parcelas inadimplentes. Esse é o mecanismo mais utilizado dentre as instituiçōes de microcrédito, sob o argumento de que a condição de inadimplente é um estado provisório e nāo permanente (IBAM, op cit,, p. 80-81).

17 A título de comparação, em 2001, a oitava maior instituição brasileira de microcrédito (coordenada pela Visão Mundial em quatro diferentes Estados), quanto ao número de clientes ativos, detinha uma carteira ativa de $\mathrm{R} \$ 1.591 .880,00$ (NICHTER, GOLDMARK e FIORI, 2002, p. 21)

${ }^{18}$ Por motivos de simplificação de análise, a pesquisa se restringiu ao municipio de Ipatinga, muito embora a agência atenda (ou já tenha atendido) clientes de municípios vizinhos. Essa concentração espacial foi motivada para possibilitar uma generalização à análise dos dados, de maneira que os resultados obtidos pudessem ser confrontados entre si.

${ }_{19}$ Devido ao fato de termos focado o elemento de proporcionalidade somente no quesito número de créditos realizados, o caráter aleatório de nossa amostra acabou envolvendo uma participação feminina de $64,5 \%$, um montante superior ao encontrado no universo estabelecido, mas que não distorce a expressiva participação do público feminino $(56,1 \%)$. 
Tabela 1: Distribuição dos clientes por sexo e número de operações (\%)

\begin{tabular}{cccccc}
\hline \multicolumn{5}{c}{ Número de Operações } \\
\hline Sexo & $\mathbf{3}$ & $\mathbf{4}$ & $\mathbf{5}$ & $\mathbf{6}$ ou mais & Total \\
\hline Homens & 15,8 & 7,9 & 6,6 & 5,3 & 35,5 \\
\hline Mulheres & 26,3 & 13,2 & 10,5 & 14,5 & 64,5 \\
\hline Total & 45,1 & 25,1 & 22,1 & 19,8 & 100 \\
\hline
\end{tabular}

Dados obtidos a partir da Pesquisa de Campo.

Esse público se constitui, em grande parte, por chefes de família. Isso pode ser verificado pelos seguintes dados: em primeiro lugar, quase $70 \%$ da amostra é formada por clientes de faixa etária entre 30 a 49 anos (Tabela 2). Além disso, aproximadamente $78 \%$ do público é casado ${ }^{20} \mathrm{e}$, para a maioria de $60,5 \%$, o rendimento do micronegócio corresponde a principal fonte de renda familiar (Tabela 3). ${ }^{21}$

Tabela 2: Distribuição de entrevistados por faixa etária

\begin{tabular}{cc}
\hline Faixa etária* $^{*}$ & Clientes (\%) \\
\hline 20 a 29 anos & 13,2 \\
\hline 30 a 39 anos & 38,2 \\
\hline 40 a 49 anos & 30,3 \\
\hline 50 a 59 anos & 14,5 \\
\hline Acima de 60 anos & 3,9 \\
\hline
\end{tabular}

Dados obtidos a partir da Pesquisa de Campo.

A tabela 4 ilustra a distribuição do grau de escolaridade de nossa amostra. Inicialmente, fica evidente a elevada participação de pessoas com nível de escolaridade até o Primeiro Grau (quase $58 \%$ ), um indício bastante relevante de que o programa está se concentrando em direção ao público-alvo com baixo grau de escolaridade.

${ }^{20}$ Cerca de $12 \%$ afirmou ser solteiro, enquanto aproximadamente $10 \%$ optou por outro tipo de resposta (Pesquisa de Campo).

${ }^{21}$ Para uma parcela superior a um terço dos clientes, o micronegócio constitui-se em sua única fonte de renda. 
Tabela 3: Participação da microempresa na estrutura de renda familiar

\begin{tabular}{cc}
\hline Participação da renda da microempresa & Clientes (\%) \\
\hline Fonte única de Renda Familiar & 35,5 \\
\hline De $60 \%$ a $80 \%$ da Renda Familiar & 22,4 \\
\hline De $40 \%$ a $59,9 \%$ da Renda Familiar & 26,3 \\
\hline Menos de 40\% da Renda Familiar & 15,8 \\
\hline Principal fonte de Renda Familiar (acima de 50\%) & 60,5 \\
\hline
\end{tabular}

Dados obtidos a partir da Pesquisa de Campo.

Tabela 4: Distribuição dos clientes segundo o grau de escolaridade (\%)

\begin{tabular}{ccc}
\hline Escolaridade & Total por faixa & Acumulado \\
\hline Menos de 1 ano & 1,3 & 1,3 \\
\hline De 1 a 3 anos & 3,9 & 5,2 \\
\hline Primário Completo & 21,1 & 26,3 \\
\hline $1^{\circ}$ Grau incompleto & 17,1 & 43,4 \\
\hline $1^{\circ}$ Grau completo & 14,5 & 57,9 \\
\hline $2^{\circ}$ Grau Incompleto & 5,3 & 63,2 \\
\hline $2^{\circ}$ Grau Completo & 21,1 & 84,2 \\
\hline Superior incompleto & 7,9 & 92,1 \\
\hline Superior Completo & 7,9 & 100 \\
\hline
\end{tabular}

Dados obtidos a partir da Pesquisa de Campo.

Se aprofundarmos a análise, verificamos que o valor máximo modal está concentrado em duas faixas: na parcela de clientes que possui apenas a formação de Primário Completo e nos que possuem o Segundo Grau Completo (mais de um quinto dos clientes em cada uma dessas faixas de formação escolar). Além disso, se adicionarmos ao primeiro dado o grupo de pessoas com escolaridade até três anos, isso significa que pouco mais de um quarto dos clientes possuem no máximo quatro anos de estudo. ${ }^{22}$

${ }^{22}$ Ainda assim, deve ser ressaltada a significativa participação de pessoas que possuem escolaridade superior completa ou incompleta, atingindo quase $16 \%$. 
Para construirmos um quadro geral do perfil de qualidade de vida dos microempreendedores, utilizamos dados da média mensal da "Renda Familiar per capita" de nossa amostra de microempreendedores. Essas informações estão presentes no Relatório Operacional interno, realizado pelo Banco Popular. ${ }^{23} \mathrm{~A}$ partir desses dados, a proposta é analisar a política de focalização de público-alvo do Banco Popular.

A tabela 5 reúne as informações do relatório que precedeu a primeira operação de crédito do conjunto de microempreendedores, classificados da seguinte forma: na primeira coluna, os clientes estão distribuídos, segundo faixa de renda per capita, enquanto a coluna seguinte traz os dados de forma agregada. Diante desses dados, fica evidente a presença de dois fatores característicos. Em primeiro lugar, a preponderância dos clientes com renda entre $\mathrm{R} \$ 100,01$ a $\mathrm{R} \$ 400,00$ : aproximadamente $60 \%$ estão nessa situação. O segundo fator, no entanto, aponta exatamente para a profunda heterogeneidade de distribuição de renda entre os microempresários: enquanto $6,6 \%$ destes tinham - no momento de entrada no Banco Popular - uma renda per capita máxima de $R \$ 100,00$, uma parcela significativa das pessoas $(15,8 \%)$ possuía uma renda superior a $\mathrm{R} \$ 600,00$ para cada membro de seu domicílio.

Tabela 5: Distribuição dos clientes por faixa de renda familiar mensal média per capita*

\begin{tabular}{lcc}
\hline Renda per capita (R\$) & Total (\%) & Agregado (\%) \\
\hline 1. De 60,01 a 100,00 & 6,6 & 6,6 \\
\hline 2. De 100,01 a 200,00 & 19,7 & 26,3 \\
\hline 3. De 200,01 a 300,00 & 28,9 & 55,3 \\
\hline 4. De 300,01 a 400,00 & 10,5 & 65,8 \\
\hline 5. De 400,01 a 600,00 & 18,4 & 84,2 \\
\hline 6. Acima de 600,01 & 15,8 & 100,0 \\
\hline
\end{tabular}

Dados obtidos junto ao Relatório Interno do Banco Popular.

* Valores padronizados referentes ao período de janeiro de 2000 .

${ }^{23} \mathrm{~A}$ justificativa para essa consulta foi que, no nosso entendimento, por motivos contratuais, essas informaçōes teriam um caráter mais fiel no "Relatório", em comparaçāo com nossa pesquisa. 
Para tornar mais claro nossa avaliação sobre a posição sócio-econômica dos clientes do Banco Popular, classificamos esses indivíduos de acordo com a escala de distribuição de renda per capita média dos cinco extratos da população municipal (cujos valores estão apresentados em anexo). Esse é o resultado ilustrado pela TAB. 6, que apresenta a parcela de clientes possuidores de renda per capita inicial abaixo da média do respectivo quinto da população de Ipatinga.

Tabela 6: Renda per capita dos clientes em relação à média dos extratos da população

\begin{tabular}{cc}
\hline Renda per capita inicial & Agregado (\%) \\
\hline 1. Abaixo da média do $1^{\circ}$ quinto & 0,0 \\
\hline 2. Abaixo da média do $2^{\circ}$ quinto & 6,6 \\
\hline 3. Abaixo da média do $3^{\circ}$ quinto & 23,7 \\
\hline 4. Abaixo da média do $4^{\circ}$ quinto & 56,6 \\
\hline 5. Abaixo da média do $5^{\circ}$ quinto & 97,4 \\
\hline
\end{tabular}

Fonte: Relatório Interno do Banco Popular e Atlas do Desenvolvimento Humano (2003).

Podemos verificar que nenhum indivíduo de nossa amostra era possuidor de renda per capita inferior a média dos $20 \%$ da população mais pobre de Ipatinga. O percentual de clientes, no entanto, vai assumindo valores crescentes a cada faixa da população de maior riqueza até atingir seu auge, entre os valores médios de renda do terceiro e do quarto quintil, a partir da onde volta a cair - somente $2,6 \%$ dos clientes tinham renda média superior aos $20 \%$ mais ricos do município.

Dentre as atividades mais freqüentes, o destaque fica para o comércio, representado por $46 \%$ da amostra avaliada. Por outro lado, a parcela de empreendimentos voltados para a produção de bens atinge pouco menos de $28 \%$, percentual ligeiramente superior ao das atividades de prestação de serviços (26\%). Esses resultados estão expressos no tabela $7 .{ }^{24}$

${ }^{24}$ Duas observações devem ser feitas: 1) O Banco Popular trabalha fundamentalmente com um universo urbano, excluindo atividades agropecuárias; 2) Por se tratar de atividades com baixa participação de ativos fixos, optamos pela denominação "produção de bens", e não "indústria" (em especial: vestuários, calçados, alimentos e marcenarias). 
Tabela 7: Distribuição setorial dos microempreendimentos

\begin{tabular}{cc} 
& $\%$ \\
\hline Produção de bens & 27,7 \\
\hline Serviços & 26,3 \\
\hline Comércio & 46,1 \\
\hline
\end{tabular}

Dados obtidos a partir da Pesquisa de Campo.

Na verdade, como pôde ser constatada pela pesquisa de campo, a característica mais presente, dentre o público participante, são seus traços de informalidade. Isso é, são empreendimentos familiares, de pequeno porte, pouco capitalizado e que contam com uma organização produtiva, em que não há separação definida entre as esferas do empresário e do trabalhador. ${ }^{25}$

A estrutura de postos de ocupação é uma boa proxy do porte dessas microempresas e de sua natureza de informalidade. Em primeiro lugar, notou-se um representativo volume de ocupações que envolvem os próprios familiares - 33,6\% dos postos, segundo apurado pela pesquisa de campo.

Uma segunda característica importante é o baixo poder de absorção de mão-de-obra dessas unidades. Se desconsiderarmos a figura do microempresário - também um integrante direto da esfera do trabalho - os empreendimentos tinham inicialmente uma relação média de apenas 1,32 posto, incluindo as várias formas de relação de trabalho permanente (desde 0 assalariado até o ajudante não remunerado). Essa proporção passou para 1,88 posto, quando considerado o período pós-microcrédito. ${ }^{26}$

Na tabela 8, está colocado o quadro inicial de emprego gerado, dividido por faixas e distribuído de acordo com o setor de atividade. Como é possível observarmos, o valor máximo modal para as atividades de produção de bens e comércio está associado às unidades que não mantinham nenhum posto de ocupação no seu momento de início das operações de crédito.

25 Conceito de "informalidade" segue orientações da OIT - Organização Internacional do Trabalho (IBGE, 1999; p. 18-19; CACCIAMALI, 2000, p. 155).

${ }^{26}$ Nesse aspecto, o salário fixo é a principal forma de remuneração nas microempresas. Isso ocorre para $55,9 \%$ dos empregados, enquanto $16,8 \%$ recebem como pagamento um valor proporcional ao trabalho (comissão) e os restantes $27,27 \%$ dos ocupados trabalham sem remuneração. Outra característica é que apenas um terço dos ocupados possuem carteira de trabalho assinada (dados apurados na pesquisa de campo). 
O setor de serviços era assim o que possuía um maior poder de absorção de postos de ocupação, embora limitado ao montante médio de 1,55 posto por unidade.

Tabela 8: Distribuição setorial do quadro de empregados

\begin{tabular}{ccccccc}
\hline \multirow{2}{*}{ Setor } & \multicolumn{5}{c}{ Número de empregados (\%) } & \multirow{2}{*}{ Média } \\
\cline { 2 - 6 } & $\mathbf{0}$ & $\mathbf{1}$ & $\mathbf{2}$ & $\mathbf{3}$ a 4 & $\mathbf{5}$ a $\mathbf{7}$ & \\
\hline Produção de bens & 48,0 & 19,0 & 9,5 & 18,5 & 5,0 & 1,29 \\
\hline Serviços & 25,0 & 35,0 & 20,0 & 15,0 & 5,0 & 1,55 \\
\hline Comércio & 42,9 & 28,6 & 11,4 & 14,2 & 2,9 & 1,2 \\
\hline
\end{tabular}

Dados obtidos juntos aos entrevistados a partir da Pesquisa de Campo.

Outro ponto a ser tratado refere-se ao local de funcionamento das microatividades, no qual percebemos uma certa diversidade de situações. Conforme constatado pela pesquisa, no momento de início de suas operações com o BP, o local de trabalho era distribuído entre a casa do empreendedor, imóvel exclusivo ou mesmo em feiras ou em comércio ambulante.

Tabela 9: Local de funcionamento do micronegócio (\%)

\begin{tabular}{cc}
\hline i. Casa do empreendedor & 23,7 \\
\hline ii. Imóvel exclusivo alugado & 36,8 \\
\hline iii. Imóvel exclusivo próprio & 26,3 \\
\hline iv. Cômodo anexo a sua casa & 7,9 \\
\hline v. Ambulante & 6,6 \\
\hline vi. Feiras & 9,2 \\
\hline
\end{tabular}

Dados obtidos juntos aos entrevistados a partir da Pesquisa de Campo.

A soma dos resultados é superior a 100\%, pois as respostas são múltiplas.

Segundo a TAB. 9, o local mais comum $(63,1 \%)$ de funcionamento do empreendedor é um imóvel especial, exclusivo de seu endereço residencial (itens ii e iii). A maior parte dos empresários nestas condições é responsável pelo pagamento de aluguel dessa área $(36,8 \%)$, mas também é relevante o tamanho do conjunto de clientes possuidores do local de funcionamento de seu negócio 
(26,3\%). Por outro lado, a própria casa do microempresário (itens i e iv) também mostra ser um local freqüentemente utilizado para compor sua atividade $(31,6 \%)$, mesmo que esta esteja em um cômodo anexo a sua residência. Cabe destacar ainda a importância dos diversos tipos de feiras (de produtos alimentícios até exposição de artesanato) existentes na cidade, seguindo um calendário corrente, que acaba por representar o local de ocupação de 9,2\% de nossa amostragem.

Finalmente, cabe notarmos a alta freqüência da irregularidade (falta de registro formal) das atividades servidas pelo Banco Popular, perante o fisco. O fato é que $68,4 \%$ dos clientes de nossa amostra eram não-registrados legalmente, desde o momento em que iniciaram suas operações de crédito, ${ }^{27}$ número que se reduziu para 61,8. Essa mudança - que não é uma exigência contratual do programa - deu-se em grande parte por fatores exógenos ao relacionamento com o Banco Popular, estando associada às possíveis exigências de mercado (grandes compradores) para cada micronegócio.

Passamos nossa análise para a estrutura de demanda do crediário de nossa amostra, para os períodos pré e pósmicrocrédito. O objetivo está em verificar a posição desse grupo de indivíduos frente ao mercado de crédito, e acompanhar o desempenho do Banco Popular, dentro dessa lógica.

Antes de tudo, destacamos um aspecto evidenciado por nossa pesquisa de campo, no que tange à expressiva participação de indivíduos possuidores de conta bancária. Essa condição era atendida por uma parcela de $86,8 \%$ dos clientes, já no momento inicial de suas operações junto ao Banco Popular. Apesar desse montante expressivo, mostraremos que a qualidade e profundidade dessa relação não se estenderam sobre o mercado de crédito produtivo.

Nossa análise tem início pela abordagem sobre a posição prévia do empreendedor frente ao mercado de crédito, ou seja, investigando quais eram as principais práticas de crédito utilizadas pelos indivíduos antes de efetivada sua condição de cliente junto ao Banco Popular.

${ }^{27}$ Essa informação foi obtida no próprio relatório de controle interno sobre os clientes por parte do Banco Popular. 
Tabela 10: Principais formas de crediário utilizado no período que precede o microcrédito

\begin{tabular}{cc}
\hline Crédito & $\%$ \\
\hline 1. Fornecedores & 77,6 \\
\hline 2. Cheque pré-datado, cheque & \\
\hline especial ou cartão de crédito & 67,1 \\
\hline 3. Bancos & 40,8 \\
\hline 4. Agiota & 15,8 \\
\hline 5. Financeiras & 11,8 \\
\hline 6. Amigos/ familiares & 10,5 \\
\hline
\end{tabular}

Dados obtidos junto aos entrevistados a partir da Pesquisa de Campo. A soma dos resultados é superior a $100 \%$, pois as respostas são múltiplas.

A tabela 10 expõe esses indicadores. Podemos verificar que as duas linhas de crédito mais utilizadas eram práticas de "crédito parcelado". De fato, quase $78 \%$ das pessoas eram usuárias do crédito promovido pelo fornecedor, enquanto $67 \%$ utilizavam cheques ou cartões de crédito bancário, como fonte de financiamento de sua microempresa. Este tipo de operação representa um mecanismo de capital de giro, para aqueles que não requerem um extenso prazo para pagamento. A vantagem desse limitado prazo (em geral, máximo de cento e vinte dias) é compensada pela agilidade na obtenção do serviço. ${ }^{28}$

Quando consideramos os serviços de crédito "em dinheiro", o montante é bem reduzido: apenas 40,8\% dos clientes já haviam realizado crediário bancário. Esse resultado é importante, pois indica que a abertura de uma conta corrente não estava se refletindo no uso ou no acesso a essa modalidade clássica de financiamento. ${ }^{29}$

\footnotetext{
${ }^{28} \mathrm{Na}$ verdade, as exigências burocráticas já foram superadas em um momento precedente (em que o usuário se cadastrou na instituiçăo prestadora do serviço).

${ }^{29} \mathrm{Na}$ verdade, se considerarmos que o público investigado é potencial demandante de crédito, a raiz do problema seria de fato o acesso inadequado ao mercado de crédito do SFN. Essa seria uma evidência de que os microempreendedores representam um nicho lucrativo às instituições do SFN. O diferencial estaria simplesmente no tipo de serviço a ser oferecido para esse público (movimentação de conta bancária e não crédito, propriamente dito).
} 
A quarta posição coube ao crediário oferecido por agiotas, na forma de empréstimo ou de desconto de cheques. Cobrindo uma parcela de pouco menos de $16 \%$ dos entrevistados, os agiotas são capazzes de oferecer crédito rápido, sob um aparato de exigências burocráticas de menor peso, quando confrontado com as operações rotineiras do SFN. O problema é que essa vantagem operacional tem um "preço", expresso nas elevadas taxas de juros.

As chamadas instituiçōes financeiras formais atuavam sobre uma faixa relativamente estrita de aproximadamente $12 \%$ dos clientes. Pelo que foi possivel constatar, a grande dificuldade desse tipo serviço de crédito está no seu preço. Isso porque, muito embora opere com exigências de comprovação de renda mínima mais flexíveis em relação aos bancos tradicionais, sua taxa de juros é fixada em um patamar muito elevado, sob a justificativa de poder arcar com os altos riscos de inadimplência. O resultado é que o custo do crédito, ao superar a taxa média de retorno dos micronegócios, torna-se economicamente inviável.

Finalmente, destacamos a categoria de natureza pessoal e familiar, que respondia pelo financiamento de $10,5 \%$ dos microempresários. A característica fundamental desse "setor" é que ele representa um mecanismo "solidário" dentre as partes: de um lado, o contrato, geralmente feito de forma oral, é regido pela confiança entre os participantes, dispensando quaisquer requisitos burocráticos; por outro lado, essa facilidade não se reflete em taxas de juros elevadas (muitas vezes, elas não são sequer cobradas). ${ }^{30}$

Pode-se dizer que a participação no programa de microcrédito provocou alterações significativas na estrutura financeira dos microempreendedores. Essas foram as informações captadas, especialmente a respeito da modalidade de crédito "em dinheiro".

A tabela 11 expressa tais resultados. Primeiramente, no caso do "crédito parcelado", podemos observar uma certa estabilidade. Nesse aspecto, as estatísticas referentes a esses elementos sofreram uma ligeira variação no período pós-Banco Popular, que podem ser interpretadas como um desvio normal dentro dos padrões observados.

${ }^{30}$ Outras formas de crediário citadas envolviam instituições como o Sebrae, bancos públicos, além de cooperativas de crédito. No entanto, o difícil acesso limitava bastante sua participação $(1,3 \%)$. 
Um comportamento distinto coube às operações de crédito em dinheiro. Isso significa que, aberta a possibilidade de obtenção de empréstimo junto ao Banco Popular, este parece ter substituído os demais serviços de crédito em dinheiro. De fato, as operações de crédito bancário foram reduzidas à metade $(48,3 \%)$, que reduziram sua participação para pouco mais de um quinto dos entrevistados $(21,1 \%)$. Redução ainda maior ocorreu com o crédito de agiotas $(67 \%)$, o crédito pessoal $(55,1 \%)$ e, em especial, o crédito gerado pelas Financeiras, cuja relação foi totalmente "cortada".

Tabela 11: Principais formas de crediário pós-microcrédito

\begin{tabular}{ccc}
\hline Crédito & Participação \% & Variação \% \\
\hline 1. Fornecedores & 78,9 & 1,7 \\
\hline 2. Cheque pré-datado, cheque & & \\
\hline especial ou cartão de crédito & 64,5 & $-3,9$ \\
\hline 3. Bancos & 21,1 & $-48,3$ \\
\hline 4. Agiota & 5,3 & $-66,5$ \\
\hline 5. Amigos/ familiares & 5,3 & $-55,1$ \\
\hline 6. Financeiras & 0 & $-100,0$ \\
\hline
\end{tabular}

Dados obtidos junto aos entrevistados a partir da Pesquisa de Campo.

A soma dos resultados é superior a 100\%, pois as respostas são múltiplas.

Para investigarmos as razões dessa substancial transferência de "crédito em dinheiro" para o microcrédito, questionamos aos clientes acerca das principais vantagens do Banco Popular. Pouco mais de um terço enfatizou o papel da baixa exigência de garantias, assim como a rapidez de obtenção do crédito solicitado. $\mathrm{O}$ item mais citado, no entanto, foi o baixo valor de juros cobrados pelas operações, ressaltado por $75 \%$ dos clientes. Essa informação foi corroborada, quando questionamos a possibilidade de um empréstimo com melhores condições de juros, oriundo de outra fonte de crédito. A resposta foi contundente: mais de $90 \%$ dos entrevistados negaram a disponibilidade de crédito a juros mais baixos do que o do Banco Popular.

Essa última estatística serve de apoio para explorarmos melhor a qualidade da relação entre os usuários e o SFN. De fato, 
as estatísticas apresentadas demonstraram a dificuldade dos microempresários para obtenção de outra fonte de crédito com taxa de juros mais favorável. Ou seja, mesmo em se tratando de um conjunto de indivíduos "bancarizados" (possuidores de conta bancária), o programa de microcrédito tem-se mostrado uma importante fonte de recursos para as microempresas.

Depois desse quadro ilustrativo, procuramos construir um cenário contrafactual, para filtrar a atuação do microcrédito. Nesse sentido, nosso objetivo foi verificar o que aconteceria com o cliente, diante da hipótese da impossibilidade de obtenção de crédito dentro do padrão oferecido.

As respostas estão apresentadas na tabela 12. A maior freqüência foi dada pelas pessoas que optariam por não realizar novos empréstimos (54\%). Assim, segundo cerca de $47 \%$ dos microempresários, a melhor opção seria continuar com capital próprio, seja pelo custo representado pelas demais condições de crédito, ou mesmo pela impossibilidade de contar com o crédito bancário. Nessa mesma direção, 6,6\% dos entrevistados alegaram que a impossibilidade de recorrer ao microcrédito resultaria no encerramento de seu negócio.

Tabela 12: Condição do cliente, diante da impossibilidade do microcrédito

\begin{tabular}{cc}
\hline Opção declarada & $\%$ \\
\hline 1. Recorreria ao crédito bancário & 23,7 \\
\hline 2. Acumularia capital para ter acesso ao banco & 6,6 \\
\hline $\begin{array}{c}\text { 3. Seguiria com capital próprio } \\
\text { (juros altos e falta de acesso) }\end{array}$ & 47,4 \\
\hline 4. Recorreria a financeiras & 5,3 \\
\hline 5. Recorreria a familiares & 3,9 \\
\hline 6. Procuraria um agiota & 17,1 \\
\hline 7. Fecharia o micronegócio & 6,6 \\
\hline
\end{tabular}

Dados obtidos junto aos entrevistados a partir da Pesquisa de Campo.

A soma dos resultados é superior a $100 \%$, pois as respostas são múltiplas.

Outra parcela relevante (36\%) declarou que iria recorrer ao setor formal, na hipótese de impossibilidade de obtenção do microcrédito: grande parte optaria já pelo crédito bancário (30\%), 
enquanto $6,6 \%$ impuseram restrições de acumulação de capital e renda para tornar possível essa condição. Finalmente, a saída para $17 \%$ dos microempresários seria mesmo recorrer a agiotas, enquanto $4 \%$ optariam pelo crédito pessoal.

A impressão que ficou foi a comprovação da importância do papel representado pelo Banco Popular, ao menos para seus clientes. Isso de certa maneira se expressa por sua posição de oferecer um crédito relativamente barato, o que implicou a própria absorção dos tomadores de empréstimos de demais instituições formais ou informais.

\subsection{Análise de componentes principais}

A análise descritiva feita até aqui nos permitiu verificar uma expressiva heterogeneidade sócio-econômica dentro do quadro de clientes do Banco Popular. Nessa subseção, a proposta é aplicarmos a Análise de Componentes Principais (ACP), para explorar esse resultado.

Para isso, faremos uso de informaçōes dos relatórios do Banco Popular (em especial, indicadores de renda e riqueza), além dos dados da pesquisa de campo. O objetivo é desenvolver uma análise mais encorpada, na qual trabalharemos simultaneamente o conjunto de variáveis mais representativas de nosso campo de investigação. Nesse aspecto, foram selecionadas dezessete variáveis:

a) Faixa etária: idade do cliente no momento inicial de sua participação no programa de microcrédito: (Idade);

b) Sexo: 0 refere-se aos homens; e 1 refere-se às mulheres: (Sexo);

c) Nível de escolaridador: (Escolaridade);

d) Renda familiar per capita, no momento preliminar a suas operações de microcrédito: (Renda per capita 1);

e) Tempo de experiência profissional na atividade econômica atual, no período de início de sua participação no Banco Popular: (Experiência);

f) Retorno líquido absoluto da microempresa no período pré-operacional: (Lucro I);

g) Valor imobilizado como ativo fixo no período préoperacional: (Ativo 1 ); 
h) Valor da riqueza patrimonial do cliente no período préoperacional: (Patrimônio 1);

i) Número de postos de trabalho direto gerados pela atividade no período pré-operacional: (Emprego 1);

j) Número de operações de crédito (capital de giro ou capital fixo) realizadas junto ao Banco Popular ( $N^{\circ}$ operaçóes);

k) Tempo de participação como cliente desde a primeira operação com o Banco Popular: (Tempo de operação);

1) Valor médio do crédito obtido junto ao Banco Popular (Crédito);

m) Renda familiar per capita do microempreendedor no período pós-operacional: (Renda per capita 2);

n) Retorno líquido absoluto da microempresa no período pós-operacional: (Lucro 2);

o) Valor imobilizado como ativo fixo no período pósoperacional: (Ativo 2);

p) Valor da riqueza patrimonial acumulada pelo cliente no período pós-operacional: (Patrimônio 2);

q) Número de postos de trabalho direto gerados pela atividade no período pós-operacional: (Emprego 2).

$\mathrm{Na}$ verdade, o conjunto de variáveis abrange um espectro relativamente amplo, tratando tanto da natureza do empreendedor e de sua vida familiar, das características da microempresa e, finalmente, indicadores de sua participação junto ao Banco Popular. Para realização do trabalho, os dados originais foram transformados em variáveis categóricas, através da criação de diversas faixas de classificação.

A partir de uma matriz reunindo os dados originais devidamente padronizados (média zero e variância única), o primeiro passo de nosso processo analítico está na montagem de uma matriz de correlação, cujo conjunto de autovalores e autovetores nos possibilitou a obtenção dos respectivos coeficientes de cada componente principal. ${ }^{31}$

31 Devemos ressaltar que o poder de atuação de uma análise multivariada depende diretamente do grau de correlação (ou de associação linear) existente entre o conjunto de indicadores. No entanto, entendemos que um baixo grau de correlação não significa a pouca importância de um indicador, mas sim o caráter de dimensão especial e singular expresso por essa medida. 
Tabela 13: Total de Variabilidade dos Dados Explicado pelos Componentes

\begin{tabular}{cccc}
\hline \multicolumn{4}{c}{ Autovalores } \\
\hline Componentes & Total & \% da Variância & \% Cumulativa \\
\hline $\mathbf{1}$ & 4,85 & 28,54 & 28,54 \\
\hline $\mathbf{2}$ & 1,94 & $\dagger 1,44$ & 39,97 \\
\hline $\mathbf{3}$ & 1,73 & 10,15 & 50,13 \\
\hline $\mathbf{4}$ & 1,55 & 9,10 & 59,23 \\
\hline $\mathbf{5}$ & 1,33 & 7,80 & 67,02 \\
\hline $\mathbf{6}$ & 1,05 & 6,18 & 73,20 \\
\hline $\mathbf{7}$ & 0,73 & $\mathbf{4 , 3 2}$ & 77,52 \\
\hline $\mathbf{8}$ & 0,67 & 3,97 & 81,49 \\
\hline$\cdot$ &. &. & $\cdot$ \\
\hline$\cdot$ &. &. &. \\
\hline $\mathbf{1 7}$ & 0,11 & 0,66 & 100 \\
\hline
\end{tabular}

Elaboraçāo própria a partir da pesquisa de campo e do Relatório Interno do Banco Popular.

Dando seqüência ao trabalho, a tabela 13 é uma síntese dos resultados de uma análise feita sobre as 17 variáveis propostas acima. A leitura dos dados apresentados nos permite acompanhar qual o poder de explicação de cada um dos dezessete componentes criados por nosso instrumental analítico. A segunda coluna mostra o montante de variabilidade captado por cada componente (expresso na primeira coluna), enquanto as duas colunas à direita apresentam o resultado percentual, isolado e também acumulado (ilustrando o poder de explicação com o uso de um conjunto cujo limite é o respectivo componente). O primeiro componente, por exemplo, explica 4,85 do somatório total da variância da matriz de correlação (17, em virtude da padronização promovida), o equivalente a um percentual de 28,54 . 
Tabela 14: Formação dos seis principäis componentes

\begin{tabular}{ccccccc}
\hline & Componentes & & & & & \\
\hline & 1 & 2 & 3 & 4 & 5 & 6 \\
\hline Renda per capita 1 & 0,585 & $-0,413$ & 0,105 & 0,541 & $-0,155$ & 0,117 \\
\hline Renda per capita 2 & 0,458 & $-0,451$ & 0,130 & 0,588 & $-0,118$ & 0,258 \\
\hline$N^{\circ}$. operações & 0,156 & $-0,233$ & 0,686 & $-0,491$ & 0,008 & 0,047 \\
\hline Sexo & $-0,161$ & $-0,167$ & 0,465 & 0,371 & 0,403 & $-0,042$ \\
\hline Idade & $-0,199$ & 0,491 & 0,437 & 0,465 & $-0,010$ & 0,162 \\
\hline Escolaridade & 0,267 & $-0,537$ & $-0,245$ & 0,030 & 0,484 & $-0,111$ \\
\hline Crédito & 0,693 & 0,203 & 0,228 & $-0,003$ & 0,064 & 0,050 \\
\hline Experiência & $-0,241$ & 0,573 & 0,233 & 0,074 & $-0,281$ & 0,320 \\
\hline Tempo de operação & 0,305 & $-0,211$ & 0,679 & $-0,350$ & 0,133 & $-0,062$ \\
\hline Emprego 1 & 0,528 & 0,412 & $-0,077$ & 0,149 & 0,259 & $-0,257$ \\
\hline Emprego 2 & 0,478 & 0,476 & 0,086 & 0,205 & 0,198 & $-0,555$ \\
\hline Lucro 1 & 0,640 & $-0,219$ & $-0,064$ & $-0,036$ & $-0,504$ & $-0,321$ \\
\hline Lucro 2 & 0,638 & 0,018 & 0,104 & $-0,020$ & $-0,585$ & $-0,226$ \\
\hline Ativo1 & 0,706 & 0,161 & $-0,352$ & $-0,005$ & 0,121 & 0,256 \\
\hline Patrimônio 1 & 0,678 & 0,088 & $-0,192$ & $-0,300$ & 0,043 & 0,439 \\
\hline Patrimônio 2 & 0,826 & 0,123 & 0,061 & $-0,163$ & 0,117 & 0,105 \\
\hline Ativo2 & 0,737 & 0,228 & $-0,009$ & $-0,050$ & 0,241 & 0,146 \\
\hline
\end{tabular}

Método: Análise de Componentes Principais, desenvolvido a partir do programa SPSS.

Elaboração própria a partir dos dados da pesquisa de campo e do Relatório Interno do Banco Popular.

Nossa proposta é a utilização de um conjunto de seis componentes principais (35\% das medidas originais), que tiveram a capacidade de explicar um pouco a mais de que $73 \%$ do objeto de estudo. 32

A tabela 14 apresenta a participação das variáveis na formàção de cada componente. A primeira dimensão, responsável por aproximadamente $28,5 \%$ do total de variância - o principal compo-

${ }^{32}$ Não existe na literatura especializada uma regra unica e absoluta quanto ao número de componentes principais que devem ser utilizados. Alguns autores, como Ferreirá (1996, p. 236-237), propōem um valor mínimo de $70 \%$ de poder de explicaçāo sobre a variância observada. Manly (1986), por seu turno, destaca que a seleçāo pode se dar sobre os componentes responsáveis por uma variância superior à verificada pelas variáveis originais padronizadas (variância unitária). 
nente - é composta principalmente por variáveis financeiras. Isso envolve indicadores de renda familiar e empresarial, sempre para os períodos pré e pós-operacional: "Renda Familiar per capita", "Lucros" e "Patrimônio físico-financeiro". Adicionalmente, deve-se colocar que esse diferencial promovido pela riqueza financeira tem sido acompanhado por dois elementos: a exigência por um crédito de maior magnitude e um maior poder de geração de postos de ocupação. Na verdade, essa associação pode ser interpretada como uma conseqüência natural, uma vez que uma estrutura microempresarial de maior porte exige crédito de valor mais substantivo (restrito ao limite imposto pelo estatuto do Banco Popular), mantendo, da mesma forma, um maior poder de geração de postos de ocupação. ${ }^{33}$

O segundo componente pode ser interpretado como a heterogeneidade da formação pessoal do microempresário (para alguns autores recentes, essa variável receberia o nome de "capital humano"), o que se constituiria em um confronto entre os indicadores "experiência" e "formação escolar". Isso significa que a experiência profissional (diretamente relacionada à faixa etária) assume, em diversas atividades, um papel fundamental para a qualificação do empreendedor, a despeito do grau de escolaridade formal. Por isso, os elementos "idade" e "experiência profissional" são variáveis que caminham juntas, em um sentido contrário ao grau de escolaridade.

O terceiro componente destaca, como fator diferencial, a intensidade da participação do cliente, no programa de microcrédito. Devemos ressaltar que esse grau de intensidade explícito pelo número de operações de crédito e pelo tempo de operação do microempreendedor junto ao Banco Popular - apresentou uma relação positiva com a idade dos clientes do sexo feminino. Isso evidencia que a preponderância de participação das mulheres tem se refletido também na maior taxa de renovação das operações de crédito.

O quarto componente principal procura distinguir os clientes segundo o grau de riqueza familiar e a estrutura de operação com

\footnotetext{
${ }^{33}$ Nesse aspecto, o primeiro componente ilustra uma associação direta entre os empregos gerados e a estrutura de capital da microempresa. Esse resultado evidencia o fato de que o capital e o trabalho no cenário de uma microempresa atuam como fatores complementares e não como substitutos. A escassez excessiva de capital atua como um obstáculo à geração de empregos.
} 
- Banco Popular. Ou seja, o componente opera com um contraste entre os fatores de "Renda Familiar per capita" e $\odot$ número de operações dos clientes para com o Banco. Isso pode ser um indício de que os clientes mais pobres estão efetivamente fazendo uso mais intenso do microcrédito, em grande parte porque esta seria a melhor alternativa para esse público (enquanto o público de maior renda teria melhores condições em outras fontes de credito).

O desempenho financeiro da microempresa está sendo captado pelo quinto componente, em que está havendo um contraste entre lucratividade absoluta da atividade (períodos pré e pósoperação) e os clientes com elevado grau de formação escolar. Mais uma vez, parece estar havendo um sinal de relativa baixa importância da escolaridade dentro da qualificação profissional de um microempreendedor. Finalmente, o sexto componente está retratando uma relação inversa entre os microempresários de maior riqueza patrimonial no período pré-operacional e a estrutura de emprego gerado em um segundo momento. A razão para isso pode ser uma retração do emprego das microempresas mais capitalizadas e a maior absorção relativa de mão-de-obra das microempresas de menor patrimônio.

Por fim, desenvolvemos uma análise gráfica bidimensional para verificarmos a dispersão dos clientes, segundo os componentes analíticos de maior relevância (pouco menos de $40 \%$ do total de variância encontrada). Para isso, cada cliente foi classificado por números, para que pudesse ser identificado. O gráfico I ilustra essa relação.

Antes de iniciarmos a análise, é importante ressaltarmos dois pontos. Em primeiro lugar, a participação das variáveis nos respectivos componentes está ilustrada através de vetores, cuja direção e intensidade estão indicando qual tem sido seu papel. Os indicadores de ordem financeira estão claramente apontando para o primeiro componente (eixo vertical), enquanto os elementos de formação pessoal têm sido mais bem captados pelo segundo componente. Um segundo aspecto é que os indivíduos que mais se destacam (positiva ou negativamente) estão localizados a uma grande distância da origem dos eixos, no limite a um ângulo próximo de $45^{\circ}$, isso porque o ponto de origem deve ser interpretado como a representação da natureza média do conjunto de pessoas. Nesse sentido, o primeiro quadrante do gráfico (acima à direita) está reunindo um grupo de participantes que podem ser 
considerados como os mais estáveis dentro de seu mercado e também os de grande sucesso econômico. Isso fica explícito pela boa condição financeira alcançada por sua microempresa (patrimônio físico-financeiro e rendimento absoluto) e por sua longa vida profissional nessa mesma atividade.

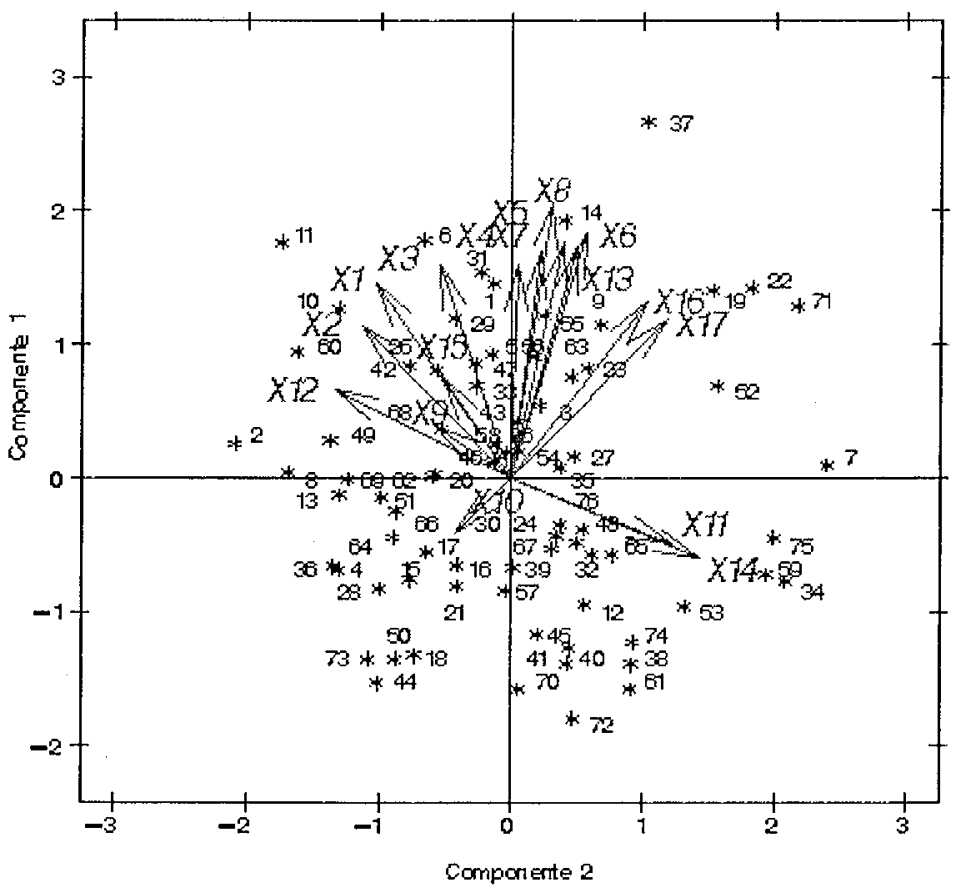

\begin{tabular}{|l|l|l|l|l|l|}
\hline $\begin{array}{l}\text { X1: Renda } \\
\text { per capita1 }\end{array}$ & X4: Lucro2 & $\begin{array}{l}\text { X7: } \\
\text { Patrimônio1 }\end{array}$ & X10: Sexo & $\begin{array}{l}\text { X13: } \\
\text { Crédito }\end{array}$ & $\begin{array}{l}\text { X15: tempo } \\
\text { operação }\end{array}$ \\
\hline $\begin{array}{l}\text { X2: Renda } \\
\text { per capita2 }\end{array}$ & X5: Ativo1 & $\begin{array}{l}\text { X8: } \\
\text { Patrimônio2 }\end{array}$ & X11: Idade & $\begin{array}{l}\text { X14: } \\
\text { Experiência }\end{array}$ & X16: Emprego1 \\
\hline X3: Lucro1 & X6: Ativ02 & $\begin{array}{l}\text { X9: } n \\
\text { operações }\end{array}$ & $\begin{array}{l}\text { X12: } \\
\text { Escolaridade }\end{array}$ & X17: Emprego2 \\
\hline
\end{tabular}

Gráfico 1: Análise conjunta dos dois principais componentes

O segundo quadrante (acima à esquerda), por sua vez, reúne o grupo de clientes economicamente emergentes, cuja boa condição financeira é compartilhada com sua juventude e uma formação escolar de maior peso. Finalmente, o terceiro e quarto quadrantes estariam reunindo os clientes de pior condição financeira, cuja diferenciação básica está na sua formação pessoal (escolaridade ou experiência profissional). 
Ao explorarmos a dispersão do grau de formação escolar do público entrevistado - o eixo horizontal do gráfico 1 - a importância dessa análise está em acentuar a ausência de uma relação existente entre o grau de escolaridade e o desempenho econômico das microempresas - o que estaria sendo refletido pelo eixo vertical. Essa informação vem a reforçar uma característica muito forte das atividades econômicas do setor informal.

Finalmente, resta colocarmos que outras estruturas bidimensionais também podem ser obtidas a partir de combinações dos diversos componentes. Entendemos, porém, que seu uso não promoveria maiores contribuições ao nosso trabalho analítico.

\section{Conclusões}

Podemos dizer que os programas de microcrédito financeiramente viáveis têm sido muitas vezes tratados como a panacéia para o combate à pobreza. Mesmo assumindo como positivos os impactos proporcionados por tais programas, o fato é que a própria estrutura de funcionamento que vem sendo proposta por órgãos oficiais (envolvendo entidades como Banco Mundial, BID, BNDES e Governo Federal), percebemos que seu caráter "democrático" é bastante limitado.

Como foi colocado, tem havido um amplo debate a respeito dos limites de conciliação entre os dois objetivos do microcrédito. Para a linha "institucionalista", que tem sido a corrente dominante, a autonomia financeira é a maneira mais eficiente de se atingir a meta social de combate à pobreza. Esse pensamento tem sido criticado por uma série de autores da linha welfarist, que entendem que há um claro limite de convergência entre esses dois "objetivos". O argumento é que, muito embora sustentado por uma metodologia de funcionamento adequada para o público desprovido de garantias reais, o maior grau de pobreza de um prestatário inexoravelmente se reflete em uma maior vulnerabilidade financeira e, conseqüentemente, em um maior risco operacional, dentro dos moldes financistas. $\mathrm{Na}$ prática, o resultado tem sido uma postura "conservadora" dos provedores de microcrédito, que optam por operar com produtos padronizados e promover uma rígida "seleção" do conjunto de clientes, que inexoravelmente exclui a camada mais fragilizada na esfera sócio-econômica. 
$O$ resultado de nossa pesquisa de campo mostra claramente que a preocupação com a viabilidade financeira do programa de microcrédito limita sua ação enquanto mecanismo de combate à pobreza. Isso ocorre devido ao fato de este enfoque direcionar a oferta de crédito para empreendedores consolidados e com maior poder de sucesso, desconsiderando o público mais vulnerável. Este resultado, ainda que não definitivo, devido ao pouco tempo decorrido desde a implementação do programa, é compatível com outras experiências (COSTA, 2001), tanto no Brasil como no exterior.

Vale ressaltar que o fato de as estruturas do microcrédito, amplamente vigente no mundo - e particularmente no Brasil não terem alcançado sua motivação principal, de combate à pobreza, não é resultado da simples insuficiência dos "ganhos de escala" obtidos pelas diversas iniciativas (como advogado por NICHTER, GOLDMARK e FIORI, op. cit., 2002; PARENTE, 2003), mas pela própria natureza do problema. Isso porque, a camada mais pobre, pela fragilidade financeira, não vai se comportar a todo o momento como um nicho atraente para uma entidade que prioriza a viabilidade de sua carteira.

\section{Referências bibliográfias}

BARONE, F. M. et. al. Introdução ao microcrédito. Brasilia: Conselho de Comunidade Solidária, 2002. 168p.

BHATT, N., TANG, S. Making microcredit work in the United States: social, financial, and administrative dimensions of intermediation. (Paper prepared for presentation at the Fifth National Public Management Research Conference, Texas A e M University, 1999). 27p.

BHATT, N., TANG, S. The problem of transaction costs in group-based microlending: an institutional perspective. World Development, v.26, n.4, p. 623-637, Apr. 1998.

BRUSKY, B., FORTUNA, J. P. Entendendo a demanda para as microfinanças no Brasil: um estudo qualitativo em duas cidades; programa de desenvolvimento institucional. Rio de Janeiro: BNDES, 2002. 65p.

CANUTO, O. Crédito para pequenas e médias empresas no Brasil. In:Castro, Ana Célia (Org.) Desenvolvimento em debate: painéis do desenvolvimento brasileiro II. Rio de Janeiro: Mauad: BNDES, 2002. Painel: micro, pequenas e médias empresas, p. 119-138. CACCIAMALI, M. C. Globalização e processo de informalidade. Economia e Sociedade, n. 14, p. 153-174, jun. 2000.

COSTA, L. M. O microcrédito e a geração de emprego e renda no norte de minas: ênfase ao crediamigo do Banco do Nordeste. 2001. 126p. Dissertação (Mestrado em Economia) - Centro de Desenvolvimento e Planejamento Regional, Universidade Federal de Minas Gerais, Belo Horizonte, 2001. 
DANLEY-HARRIS, S. State of microcredit summit campaign: Report 2002. Washington: International Labor Organization (ILO), 2002. 21p.

D'EXELLE, B., BASTIAENSEN, J., ALEMÁN, M. Is microfinance really incompatible with poverty alleviation?: The local social-institutional embeddedness of rural microfinance. [2002?] 24p.

DYMSKI, G. A. Keynesian uncertainty and asymmetric information: complementary or contradictory? Journal of Post Keynesian Economics, v. 16, n. I, p. 49-54, 1993.

DYMSKI, G. A., VEITCH, J. M. Financial transformation and the metropolis: booms, busts, and banking in Los Angeles. Environmental and Planning A, v.28, p. 1233-1260, 1996.

FERREIRA, D. F. Análise multivariada. Lavras: Universidade Federal de Lavras, Departamento de Ciências Exatas, 1996. 389p.

FERRAREZI, E. O novo marco legal do terceiro setor. Brasilia: Conselho de Comunidade Solidária, 2002. 24p.

GONZÁLES VEGA, C. et al. BancoSol: el reto del crecimiento en organizaciones de microfinanzas. Columbus, Ohio: The Ohio State University, 1996 (Occasional Paper n.2345).

IBGE. Economia Informal Urbana 1997 - Unidades da federação e regiões metropolitanas da região sudeste. Rio de Janeiro: IBGE, vol. 4, 1999. $321 \mathrm{p}$.

INSTITUTO BRASILEIRO DE ADMINISTRAÇĀO MUNICIPAL - IBAM. Perspectivas de expansão das microfinanças no Brasil: marco legal, capitalização e tecnologia. Rio de Janeiro: Núcleo de Economia Local (NEL) da Área de Desenvolvimento Econômico e Social (DES) do IBAM, 2001. 171p.

MANLY, B. F. J. Multivariate statistical methods. London: University of Warwich: Chapman and Hall Ltd., 1986.

MORDUCH, J. The microfinance schism. World Development, v.28, n.4. p. 617-629, 2000.

NAVAJAS, S. et al. Microcredit and the poorest of the poor: theory and evidence from Bolivia. The Ohio State University, Economics and Sociology, Occasional Paper 2524, dec. 1998.

NICHTER, S., GOLDMARK, L., FIORI, A. Entendendo as microfinanças no Brasil. Rio de Janeiro: PDI/BNDES, 2002.61p.

PARENTE, S. O mercado financeiro e a população de baixa renda. [s.l.]: CEPAL, Brasil, 2003.63p.

ROSEMBERG, R. Microcredit interest rates. Washington, D.C.: Consultative Group to Assist the Poorest - CGAP, 1996.12p. (Occasional Paper, 1)

SCHREINER, M. A cost-effectiveness analysis of the Grameen Bank of Bangladesh. St. Louis: Washington University in St. Louis, 2001. 48p.

SINGER, P. Introdução à economia solidária. São Paulo: Fundação Perseu Abramo, 2002. 127p

STIGLITZ, J., WEISS, A. Credit rationing in markets with imperfect information American Economic Review, v.71, n.3, p. 393-410, Jun. 1981.

TOSCANO, I. Microcrédito: da iniciativa local ao centralismo estatal. São Paulo: Instituto Polis, 2002. 20p. 
WOLLER, G. M. From market failure to marketing failure: market-orientation as the key to deep outreach in microfinance. Journal of International Development, v.14, n.3, p. 305-324, 2002.

WOLLER, G. M., DUNFORD, C. and WOODWORTH, Warner. Where to microfinance? International Journal of Economic Development, v.1, n.1, p. 29-64, 1999.

WRIGHT, G. A. N., Microfinance systems: designing quality financial services for the poor. Dhaka, Bangladesh: The University, 2000. 283p.

YARON, J., BENJAMIN, M., CHARITONENKO, S. Promoting efficient rural financial intermediation. The World Bank Research Observer, v.1, n.2, p.147-170, Aug. 1998.

YUNUS, M. O banqueiro dos pobres. São Paulo: Ática, 2000. 343p. 